\title{
PENGARUH MODEL PROBING PROMTING TERHADAP HASIL BELAJAR SISWA DALAM PEMBELAJARAN SEJARAH KELAS X SMA NEGERI 15 MEDAN T.A 2018/2019
}

\author{
Oleh:
}

Abd. Haris Nasution

Adelia Safitri

\begin{abstract}
ABSTRAK
Penelitian ini bertujuan untuk mengetahui pengaruh model Probing Promting dalam meningkatkan hasil belajar siswa dalam pembelejaran sejarah. Penelitian ini merupakan penelitian kuantitatif dengan desain penelitian eksperimen, yaitu ada perbedaan perlakukan antara kedua kelas eksperimen dan kelas kontrol agar dapat dilihat perbedaannya. Populasi penelitian ini adalah kelas X SMA Negeri 15 Medan yang terdiri dari 6 kelas dengan jumlah seluruh siswa 210 orang. Pengambilan sampel dalam penelitian ini menggunakan teknik acak atau random sampling, dimana kelas eksperimen adalah kelas X Ips 1 yang diajarkan dengan menggunakan model probing promting dan yang menjadi kelas kontrol adalah kelas X Ips 2 yang diajarkan metode ceramah. Berdasarkan hasil penelitian nilai rata-rata siswa pada kelas X Ips 1 sebesar 83,82, sedangkan nilai rata-rata siswa kelas X Ips 2 adalah sebesar 73,55. Adanya perbedaan hasil belajar tersebut juga terbukti melalui pengujuan hipotesis dengan menggunakan uji-t dan taraf kepercayaan $\alpha=0,05$, dimana $t_{\text {hit }}>t_{\text {tabel }}$ yaitu 5,24 $>1,6697$ dengan demikian dalam penelitian ini $H_{0}$ ditolak dan $H_{a}$ diterima, sehingga dapat disimpulkan bahwa ada perbedaan hasil belajar yang signifikan antara model probing promting dengan metode ceramah yaitu lebih tinggi hasil belajar yang menggunakan model probing promting.
\end{abstract}

Kata Kunci : Probing Promting, Hasil Belajar, Sejarah. 


\section{PENDAHULUAN}

Pendidikan memegang peran yang sangat penting bagi kelangsungan dan perkembangan kehidupan manusia. Melalui pendidikan sumber daya manusia yang berkualitas sebagai motor penggerak kemajuan dan pembangunan suatu bangsa. Bangsa Indonesia sebagai bangsa yang berkembang terus berupaya meningkatkan sumber daya manusia melalui pendidikan nasional. Pendidikan merupakan faktor utama dalam pembentukan pribadi manusia. Tujuan pendidikan pada dasarnya adalah mengantarkan manusia-manusia pada perubahan tingkah laku, intelektual, moral maupun sosial.

Pembelajaran merupakan proses interaksi yang terjadi antara guru dan siswa agar siswa mendapat pengalaman belajar dari kegiatan tersebut. Pembelajaran didalam kelas merupakan bagian yang sangat penting dalam proses pendidikan. Jika pembelajaran didalam kelas bermutu maka akan menghasilkan output yang berkualitas pula. Guru memiliki peran penting dalam mengorganisasikan kelas sebagai bagian dari proses pembelajaran dan siswa sebagai subjek yang sedang belajar.

Mengingat pentingnya pembelajaran sejarah, maka sangat diharapkan siswa untuk menguasai materi sejarah, namun pada kenyataannya penguasaan terhadap materi sejarah cenderung rendah, hal ini dapat dilihat dari hasil belajar siswa. Dimana pada proses pembelajaran guru pada umumnya dalam penyampaian materi hanya menggunakan metode ceramah dan mencatat, guru berperan sebagai teacher center sedangkan siswa cenderung pasif. Dengan metode ceramah yang digunakan oleh guru, siswa kurang memahami materi yang disampaikan, sehingga pembelajaran sejarah terkesan membosankan dan mining less, maka mengakibatkan hasil belajar siswa menjadi rendah.

Berdasarkan hasil observasi di SMA Negeri 15 Medan diperoleh keterangan hasil belajar siswa dalam pembelajaran sejarah kelas X tergolong rendah. Dari hasil ulangan siswa banyak siswa yang belum mecapai KKM, dimana kriteria ketuntasan minimal dalam pelajaran sejarah di SMA N 15 Medan adalah 75. SMA N 15 sudah didukung dengan sarana prasarana yang memadai seperti, perpustakaan yang memadai, lap komputer, dan infocus disetiap kelas tersedia, serta fasilitas 
ekstrakulikuler juga memadai, bagaimana menanfaatkan fasilitas yang ada dalam mendukung penbelajaran yang lebih menarik minat siswa.

Salah satu pemecahan masalah yang diatas, maka sangat diperlukan penggunaan model pembelajaran agar dapat keaktifan peserta didik terhadap pelajaran sejarah. Adapun model pembelajaran yang digunakan oleh guru sebagai alternatif salah satunya yakni model pembelajaran Probing Promting. Model pembelajaran ini guru menyajikan serangkaian pertanyaan yang bersifat menggali dan menuntut sehingga terjadi proses berfikir dan mengaitkan pengetahuan dan pengalaman siswa dalam belajar. Selanjutnya, siswa mengkrontuksi konsep, prinsip, dan aturan menjadi pengetahuan baru. Model pembelajaran ini yakni proses tanya jawab dengan menunjuk siswa secara acak sehingga setiap siswa harus aktif dalam proses pembelajaran, karena setiap saat ia bisa saja dilibatkan dalam proses tanya jawab. Kemudian suasana kelas akan panik dan siswa merasa cemas apabila ia akan mendapatkan pertanyaan secara acak tersebut, disini lah peran guru tetap bersikap ramah dan menyenangkan sehingga membuat suasana kelas yang semula tidak Kondusif akan menjadi lebih tertib dan nyaman. Bagi siswa yang benar akan mendapatkan penghargaan berupa hadiah, namun guru juga harus menghargai jawaban siswa yang salah karna salah adalah proses belajar dan telah berpartisipasi.

\section{PEMBAHASAN}

\section{A. Perbandingan hasil Pretest dan Posttest kelas Eksperimen}

Langkah pertama yang dilakukan dalam penelitian ini ialah melakukan pretest. Pre-test dilakukan pada kelas Eksperimen dan kelas Kontrol dengan menggunakan instrument yang sama. Hasil pre-test kelas eksperimen menunjukkan bahwa dari 34 siswa, 3 orang siswa memperoleh skor 25, 4 siswa memperoleh skor 30, 3 siswa memperoleh skor 35, 6 siswa memperoleh skor 40, 6 siswa memperoleh skor 45, 3 siswa memperoleh skor 50, 4 siswa memperoleh skor 55 dan 4 siswa memperoleh skor 60. Hasil pre-test pada eksperimen dapat diamati pada table distribusi frekuensi berikut ini: 
Tabel 1.

Daftar distribusi frekuensi Pre-Test kelas eksperimen

\begin{tabular}{|c|c|c|c|c|}
\hline No & Nilai & Freq & Rata-Rata & Standar Deviasi \\
\hline 1 & $24-30$ & 7 & \multirow{6}{*}{43,08} & \multirow{6}{*}{10,76} \\
\hline 2 & $31-37$ & 3 & & \\
\hline 3 & $38-44$ & 6 & & \\
\hline 4 & $44-50$ & 10 & & \\
\hline 5 & $51-57$ & 4 & & \\
\hline 6 & $58-64$ & 4 & & \\
\hline
\end{tabular}

Setelah model Problem Prompting dilakukan, peningkatan signifikan terlihat pada hasil belajar kelas eksperimen. Peningkatan hasil belajar tersebut dapat terlihat dari hasil post-test yang telah diberikan. Hasilnya; dari 34 orang siswa terdapat 1 siswa memperoleh skor 67, 2 siswa dengan skor 69, 1 siswa dengan skor 70, 3 siswa dengan skor 71, 1 siswa dengan skor 73, 1 siswa dengan skor 74, 2 siswa dengan skor 80, 1 siswa dengan skor 81, 2 siswa dengan skor 85, 2 siswa dengan skor 87,4 siswa dengan skor 88,4 siswa dengan skor 89, 5 siswa dengan skor 90, 3 siswa dengan skor 91, 1 siswa skor 92 dan 1 siswa dengan skor 97. Berikut data hasil posttest dalam table distribusi frekuensi:

\section{Tabel 2.}

Daftar distribusi post-test frekuensi kelas eksperimen sebagai berikut :

\begin{tabular}{|c|c|c|c|c|}
\hline No & Nilai & Freq & Rata-Rata & Standar Deviasi \\
\hline 1 & $61-67$ & 1 & \multirow{6}{*}{83,52} & \multirow{6}{*}{8,66} \\
\hline 2 & $68-74$ & 8 & & \\
\hline 3 & $75-81$ & 3 & & \\
\hline 4 & $82-88$ & 8 & & \\
\hline 5 & $89-95$ & 13 & & \\
\hline 6 & $96-100$ & 1 & & \\
\hline
\end{tabular}




\section{B. Perbandingan Pretest dan Posttest Kelas Kontrol}

Hasil pengujian pada kelas Eksperimen berbeda halnya dengan hasil pada kelas control. Dari 34 siswa, 1 siswa memperoleh skor 23, skor 27 ada 1 siswa, skor 33 ada 3 siswa, skor 37 ada 3 siswa, skor 40 ada 4 siswa, skor 43 ada 1 siswa, skor 47 ada 1 siswa, skor 50 ada 6 siswa, skor 53 ada 6 siswa, skor 57 ada 5 siswa, skor 60 ada 1 siswa, skor 67 ada 1 siswa, dan skor 70 ada 1 siswa. Berikut tabel daftar distribusi frekuensi pre-test kelas kontrol :

Tabel 3.

Daftar distribusi frekuensi Pre-Test kelas Kontrol

\begin{tabular}{|c|c|c|c|c|}
\hline No & Nilai & Frekuensi & Rata-Rata & Standar Deviasi \\
\hline 1 & $20-26$ & 1 & \multirow{8}{*}{47,35} & \multirow{8}{*}{10,76} \\
\hline 2 & $27-33$ & 4 & & \\
\hline 3 & $34-40$ & 7 & & \\
\hline 4 & $41-47$ & 2 & & \\
\hline 5 & $48-54$ & 12 & & \\
\hline 6 & $55-61$ & 5 & & \\
\hline 7 & $62-68$ & 1 & & \\
\hline 8 & 69-75 & 2 & & \\
\hline
\end{tabular}

Hasil post-test pada kelas kontrol yang jumlah 34 siswa, antara lain: maka skor 60 ada 3 siswa, skor 63 ada 3 orang siswa, skor 67 ada 4 orang siswa, skor 70 ada 5 orang siswa, skor 73 ada 4 orang siswa, skor 77 ada 5 orang siswa, skor 80 ada 4 orang siswa, skor 82 ada 5 orang siswa dan skor 87 ada 1 orang siswa. Berikut daftar distribusi frekuensi post-test kelas kontrol.

Tabel 4.

Daftar distribusi frekuensi Post-Test kelas Kontrol

\begin{tabular}{|c|c|c|c|c|}
\hline No & Nilai & Frekuensi & Rata-Rata & $\begin{array}{c}\text { Standar } \\
\text { Deviasi }\end{array}$ \\
\hline 1 & $54-60$ & 3 & & \\
\hline 2 & $61-67$ & 7 & & \\
\hline 3 & $68-74$ & 9 & \multirow{3}{*}{73,55} & 8,38 \\
\hline 4 & $75-81$ & 9 & & \\
\hline 5 & $82-88$ & 6 & & \\
\cline { 1 - 2 } & & & \\
\hline
\end{tabular}




\section{Uji Normalitas dan Homogenitas}

Pengujian ini dilakukandengan menggunakan uji Lieliefors (L). Uji normalitas data-data sampel dengan kriteria $L_{\text {hitung }}<L_{\text {tabel }}$ pada taraf sifnifikan $\alpha=0,05$. Dengan demikian dapat disimpulkan bahwa kedua sampel berdistribusi normal.

Untuk menguji perbedaan yang signifikan hasil belajar siswa perlu diketahui apakah kedua sampel berasal dari varians yang homogen aka perlu dilakukanuji kesamaan varians, menggunakan uji Fisher (uji F). Pada masingmasing pre-test dan post-test untuk kedua sampel diperoleh pengujian $F_{\text {hitung }}<$ $F_{\text {tabel }}$ maka diterima hipotesis nol bahwa sampel memiliki varians yang homogen. Jika sebaliknya maka varians tidak homogen.

\section{Pengujian Hipotesis}

Pengujian hipotesis dilakukan dengan dua cara yaitu Uji-t dua pihak dan Ujit satu pihak.

- Uji Pengetahuan Awal/Pre-Test Siswa (Uji-t dua pihak)

- Uji-t dua pihak untuk mengetahui kesemaan pengetahuan awal siswa pada kedua kelas. Hipotesis yang diuji berbentuk:

$H_{0}: \mu_{1}=\mu_{2}$ yaitu kelas eksperimen dan kelas kontrol memiliki kemampuan awal yang sama.

$H_{a}: \mu_{1} \neq \mu_{2}$ yaitu kelas eksperimen dan kelas kontrol mempunyai kemampuan awal yang berbeda.

Dari pengujian diperoleh $T_{\text {hit }}-1,80$ dan $T_{t a b} 1,998$, kriteria hipotesis yaitu jika $T_{\text {hit }}<T_{\text {tab }}$ maka $H_{0}$ diterima dan $H_{a}$ ditolak. Maka hasil hipotesis untuk hasil pre-test yaitu $T_{h i t}<T_{t a b}, T_{h i t}-1,80<T_{t a b} 1,998$, maka $H_{0}$ diterima yaitu pengetahuan awal siswa antara kelas eksperimen dan kelas kontrol sama.

- Uji Kemampuan Akhir/Post-Test (Uji-t satu pihak)

Uji-t satupihak dugunakan untuk mengetahui adanya perbedaan akibat pengaruh dari suatu perlakuan yaitu pengaruh model probing promting terhadap hasil belajar siswa. Hipotesis yang diuji dengan kriteria: 
$H_{0}: \mu_{1}=\mu_{2}$ yaitu tidak ada perbedaan akibat pengaruh model probing promting terhadap hasil belajar sejarah siswa kelas X SMA N 15 Medan T.A 2018/2019.

$H_{a}: \mu_{1}>\mu_{2}$ yaitu ada perbedaan akibat pengaruh model probing promting terhadap hasil belajar sejarah siswa kelas X SMA N 15 Medan T.A 2018/2019.

Hasil dari uji hipotesis post-test siswa dari kelas eksperimen dan kelas kontrol, diperoleh $T_{\text {hit }}$ 5,24 dan $T_{\text {tab }}$ 1,6697 kriteria hipotesis yaitu jika $T_{\text {hit }}>$ $T_{\text {tab }}$ maka $H_{a}$ diterima dan $H_{0}$ ditolak. Maka hasil hipotesis untuk hasil post-test yaitu $T_{\text {hit }}>T_{t a b}, T_{\text {hit }} 5,24<T_{t a b} 1,6697$, maka $H_{a}$ diterima yaitu ada perbedaan hasil belajar yang signifikan yaitu hasil belajar kelas eksperimen lebih tinggi dari kelas kontrol.

\section{Pembahasan hasil Penelitian}

Dari hasil pengujuan hipotesisi diperoleh bahwa ada perbedaan yang signifikan antara hasil belajar yang menggunakan model probing promting dan hasil belajar siswa yang menggunakan metode ceramah. Hal ini dapat dilihat dari ratarata pre-test siswa kelas eksperimen yaitu 43,68 dan setelah diberikan perlakuan dengan menerapkan model probing promting nilai rata-rata post-test 83,82, sedangkan hasil belajar siswa kelas kelas kontrol rata-rata sebelum diberikan perlakuan yaitu 47,35 dan setelah perlakuan yakni dengan menerapkan metode ceramah nilai rata-rata post-test 73,55 .

Nilai pre-test kelas eksperimen berbeda dengan nilai pre-test pada kelas kontrol. Hal ini jelas terlihat dai garis ditunjukkan oleh grafik. Awalnya nilai pretest antara kedua kelasnya memiliki nilai yang hampir sama. Untuk melihat perbedaan kemampuan awal kedua kelas dilakukan uji hipotesis dengan uji persyaratan yaitu uji normalitas dengan menggunakan uji lilifors dan uji homogenitas dengan menggunakan uji-F.

Dari hasil penelitian bahwa data siswa yang dijadikan sampel bersifat normal dan homogen. Itu terbukti dari uji normalitas dengan kriteria $L_{\text {hitung }}<$ $L_{\text {tabel }}$ pada taraf signifikan $\alpha=0,05$ pada hasil belajar pre-test dan post-test pada kedua kelas. Uji hipotesis yang digunakan dalam penelitian ini adalah uji-t dua pihak dan uji-t satu pihak. Uji-t dua pihak digunakan untuk melihat apakah 
kemampuan awal siswa yang dijadikan sampel memiliki pengetahuan yang sama atau tidak, seperti dalam penelitian kelas eksperimen (X Ips 1) dan kelas kontrol (X Ips 2) memiliki pengetahuan yang sama karena $T_{h}<T_{t}$ sehingga hipotesis nol diterima, sedangkan uji-t satu pihak digunakan untuk melihat perbedaan setelah diberikannya perlakuan pada kelas eksperimen dengan menggunakan model probing promting dan kelas kontrol menggunakan metode ceramah, ternyata hasil penelitian menunjukan adanya perbedaan hasil belajar yang signifikan yaitu hasil belajar kelas eksperimen lebih besar dari hasil belajar kelas kontrol.

Berdasarkan gambaran diatas terlihat perbedaan hasil belajar yang signifikan karena telah diterapkan model probing promting pada kelas eksperimen dan penerapan metode ceramah pada kelas kontrol. Hasil belajar antara kedua kelas terlihat dari tabel yaitu rata-rata kelas eksperimen yaitu 83,82, sedangkan kelas kontrol yaitu 73,55. Untuk melihat perbedaan hasil belajar siswa maka dilakukan uji persyaratan yaitu uji normalitas yang menunjukan data kedua kelas bersifat normal, dan uji homogenitas data kedua kelas bersifat homogen.

Uji hipotesis yaitu dengan melakukan uji-t satu pihak, untuk melihat hasil belajar antara kelas eksperimen dan kelas kontrol sama atau ada yang lebih besar setelah dilakukan perlakuan atau post-test. Dari tabel dimana $T_{\text {hitung }}>T_{\text {tabel }}$ yaitu 5,24>1,6697, ini menunjukan bahwa $H_{a}$ diterima dan $H_{0}$ ditolak. Ini berarti ada perbedaan yang signifikan antara hasil belajar kedua kelas yakni hasil belajar yang memnggunakan model probing promting lebih tinggi hasil belajarnya dengan yang menggunakan metode ceramah.

Pada saat penerapan model probing promting dikelas eksperimen ada beberapa kelebiham dibandingkan kelas kontrol yang menggunakan metode ceramah. Ketika diterapkan model probing promting di kelas eksperimen hampir seluruh siswa berperan aktif dalam kegiatan diskusi, mereka mencari informasi sesuai dengan materi pembelajaran dari berbagai sumber seperti buku dan internet.

Selain itu, ketika siswa melakukan kegiatan persentasi setiap kelompok sering terjadi perbedaan pendapan dengan kelompok lain. Mereka menggali kemampuan mereka dari sumber yang mereka kumpulkan. Diakhir pembelajaran siswa harus dapat menyimpulkan materi apa yang mereka dapatkan sebagai 
pengetahuan baru dan menanyakan kepada guru apa yang kurang mereka pahami agar terbentuk pembelajaran yang efektif.

Metode ceramah diterapkan di kelas kontrol yakni kelas X IPS 2, ketika penerapan metode ceramah ini peran guru sangat penting karena jika guru kurang tepat dalam menerapkan metode ini maka siswa akan merasa jenuh, tapi sebaliknya jika guru dalam penerapan metode ini dengan efektif, maka siswa bisa tertarik dalam belajar terutama sejarah. Ketika kelas kontrol diterapka metode ceramah, ada sebagian siswa juga yang kurang aktif dalam proses pembelajaran. Dalam metode ini juga ketika guru menjelaskan akan dibarengi dengan diskusi dan tanya jawab kepada guru maupun kepada siswa.

\section{PENUTUP}

Berdasarkan uraian hasil penelitian maka dapat diperoleh kesimpulan sebagai berikut: Dengan menggunakan Uji hipotesis dengan uji-t satu pihak, untuk melihat perbedaan hasil belajar antara kelas kontrol dan kelas eksperimen. Dari tabel dimana $T_{\text {hitung }}>T_{\text {tabel }}$ yaitu 5,24 $>1,6697$, ini menunjukan bahwa $H_{a}$ diterima dan $H_{0}$ ditolak. Ini berarti ada perbedaan yang signifikan antara hasil belajar kedua kelas yakni hasil belajar yang memnggunakan model probing promting lebih tinggi hasil belajarnya dengan yang menggunakan metode ceramah. Hasil belajar siswa yang menggunakan model probing promting memiliki rata-rata nilai 83,82 dengan jumlah sampel sebanyak 34 orang siswa. Hasil belajar dengan penerapan metode ceramah memiliki nilai rata-rata 73,55 dengan jumlah sampel sebanyak 34 orang siswa. Ada pengaruh model probing promting lebih tinggi dibandingkan dengan yang menggunakan metode ceramah. 


\section{Referensi}

Arikunto, Suharsimi. 2013. Dasar-dasar Evaluasi Pendidikan. Jakarta :PT. Bumi Aksara.

Aswan, Zain. (2015). “Strategi Belajar Mengajar”. Jakarta : PT RinekaCipta

Azhar, saifuddin. 2005. Tes Prestasi. Yogyakarta: PT Pustaka Pelajar

Daliman. 2012. Model Penelitian Sejarah. Yogyakarta: Ombak ke Praktik. Jakarta :PT. Raja Grafindo Persada.

Mudlofir, Ali dan Fatimatur, Evi. 2016. Desain Pengantar Inovatif Dari Teori ke praktik. Jakarta: PT Rajagrafindo Persada.

Ngalimun. (2017). "Strategi Dan Model Pembelajaran “. Yogyakarta : Aswaja Pressindo.

Pupuh dan Sobry. 2015. Srategi Belajar Mengajar Melalaui Penanaman Konsep Umum dan Konsep Islami. Jakarta: Reflika Aditama.

Pupuh ddk. 2017. Strategi Belajar Mengajar. Jakarta:PT. Penerbit Aditama

Purwanto, Ngalim. 2013. Prinsip-Prinsip dan Teknik Evaluasi Pengajaran. Bandung :PT Remaja Rosdakarya.

Sanjaya, Wina. 2012. Perencanaan dan Desain Sistem Pembelajaran. Jakarta:PT. Kencana.

Shoimin, Aris. 2013. 68 Model Pembelajaran Inovatif Dalam Kurikulum 2013. Yogyakarta :Ar-ruzz Media.

Sudjana, Nana. 2010. Penilaian Hasil Proses Belajar Mengajar. Bandung :PT Remaja Rosdakarya.

Sudjana. (2005). “Metode Statistika”. Bandung : PT Tarsito.

Sugiono. (2015). Metode Penelitian Pendidikan Pendekatan Kuantitaif, Kualitatif, dan $R \& D$. Bandung :Alfabeta.

Yamin, Martinis. (2013). Desain Pembelajaran Berbasis Tingkat Satuan. Jakarta Selatan :Referensi. 